\title{
Factors Conditioning the Potential Effects TiO2 NPs Exposure on Human Microbiota: a Mini-Review
}

\author{
Ewa Baranowska-Wójcik ${ }^{1}$ (D) \\ Received: 8 December 2020 / Accepted: 5 January 2021 / Published online: 14 January 2021 \\ (C) The Author(s) 2021
}

\begin{abstract}
The recent years have seen a significant interest in the applications of nanotechnology in various facets of our lives. Due to their increasingly widespread use, human exposure to nanoparticles (NPs) is fast becoming unavoidable. Among the wide group of

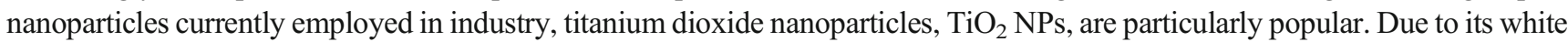
colour, $\mathrm{TiO}_{2}$ is widely used as a whitening food additive (E 171). Yet, there have been few studies aimed at determining its direct

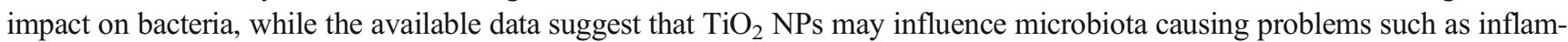
matory bowel disease, obesity, or immunological disorders. Indeed, there are increasing concerns that its presence may lead to intestinal barrier impairment, including dysbiosis of intestinal microbiota. This article aims to present an overview of studies conducted to date with regard to the impact of $\mathrm{TiO}_{2} \mathrm{NPs}$ on human microbiota as well as factors that can affect the same. Such information is necessary if we are to conclusively determine the potential toxicity of inorganic nanoparticles.
\end{abstract}

Keywords $\mathrm{TiO}_{2} \mathrm{NPs} \cdot$ Microbiota $\cdot$ Nanoparticles $\cdot$ Bacterial $\cdot$ Human gastrointestinal microbiota

\section{Introduction}

In recent years, the use of nanomaterials in food products has been observed to grow rapidly on a continuous basis, which inevitably increases the risk of adverse health effects resulting from their uncontrolled release $[1,2]$.

Numerous in vitro and in vivo studies conducted to date have confirmed the toxicity of $\mathrm{TiO}_{2}$ NPs against a human organism, including effects related to cellular cycle alterations, nuclear envelope contraction, and apoptosis [3, 4]. In vivo studies further demonstrated that after inhalation or oral exposure, $\mathrm{TiO}_{2}$ NPs accumulate in, e.g. the lungs, heart, alimentary tract, liver, spleen, kidneys, and myocardium, as well as upset the homeostasis of glucose and lipid metabolism in mice and rats [5-7]. Other possible effects include dyspepsia and nutrient absorption disorders after exposure to $\mathrm{TiO}_{2}$ NPs, which may be a consequence of micro- and macroelements in the organism [8]. In the brain, $\mathrm{TiO}_{2}$ NPs can trigger protein oxidation, oxidative damage, reduction of

Ewa Baranowska-Wójcik

Ewa.Baranowska@up.lublin.pl

1 Department of Biotechnology, Microbiology and Human Nutrition, University of Life Sciences in Lublin, Skromna 8, Lublin, Poland antioxidative capacity, and increased production of ROS (reactive oxygen species) $[9,10]$.

$\mathrm{TiO}_{2}$ NPs (nanoparticles) are used as whitening or brightening additive in the food industry (coded-E171). They are commonly added to a number of products including sauces, cheeses, skimmed milk, ice-cream, and confectionary products - e.g. as coating for sweets and chewing gum [11-14]. They are also utilised in food processing and packaging, as well as added to pharmaceuticals, cosmetics, and toothpastes $[11,15,16]$. Owing to their antibacterial properties, $\mathrm{TiO}_{2} \mathrm{NPs}$ may also serve as food preservatives $[17,18]$.

$\mathrm{TiO}_{2}$ content in confectionary products, particularly in sweets, chewing gum, chocolate, and other white-coated products, can be very high, reaching up to $2.5 \mathrm{mg} \mathrm{Ti} / \mathrm{g}$ of food $[14,19]$. The lack of sufficient research data prevents the determination of the admissible, daily consumption of $\mathrm{TiO}_{2}$ NPs [19]. Based on studies conducted on animals, a safety margin of $2.25 \mathrm{mg} \mathrm{TiO}_{2} \mathrm{NPs} / \mathrm{kg} \mathrm{bm} /$ day was suggested [19]. Its daily consumption varies depending on age, body weight, and place of residence. It is nonetheless estimated that a child is likely to ingest up to 2-4 times more $\mathrm{TiO}_{2}$ NPs per $1 \mathrm{~kg}$ of body mass (Table 1) [14, 19, 20] compared to an adult. In Great Britain, children under 10 years old consume, on average, approximately $2-3 \mathrm{mg}$ of $\mathrm{TiO}_{2} / \mathrm{kg} \mathrm{bm} /$ day, while in adults this value is estimated at $1 \mathrm{mg} \mathrm{TiO}_{2} / \mathrm{kg}$ bm/day [14]. 
Table 1 Human oral exposure to $\mathrm{TiO}_{2} \mathrm{NPs}$ in food

\begin{tabular}{llll}
\hline Areas & \multicolumn{2}{c}{$\mathrm{TiO}_{2}(\mathrm{mg} / \mathrm{kg}$ bw/day $)$} & \multirow{2}{*}{ Reference } \\
\cline { 2 - 3 } & Children & Other ages & \\
\hline USA & $1-2$ & $0.2-0.7$ & {$[14]$} \\
United Kingdom & $2-3$ & 1 & {$[14]$} \\
Europe & $5.5-10.4$ & $0.2-0.4$ & {$[19]$} \\
Netherlands & 1.4 & $0.5-0.7$ & {$[20]$} \\
China (Beijing) & $0.02-3.09$ & & {$[20]$} \\
\hline
\end{tabular}

$\mathrm{TiO}_{2}\left(\mathrm{mg} / \mathrm{kg}\right.$ bw/day) - $-\mathrm{TiO}_{2} \mathrm{NPs}$ per $1 \mathrm{~kg}$ of body weight (bw) per day

The impact of $\mathrm{TiO}_{2} \mathrm{NPs}$ on the human organism has been debated for years. Both the levels of its exposure and toxicity to a human/animal organism have been subject to in-depth study and discussion. The wide-spread use of $\mathrm{TiO}_{2} \mathrm{NPs}$ in the food industry has raised considerable safety concerns and controversy $[11,21]$. Some studies conclude that $\mathrm{TiO}_{2}$ NPs may be toxic towards and have adverse effects on the cardiovascular system. Elevated expression of inflammatory cytokines such as TNF- $\alpha$, INF-g, and IL-8 in the blood, after the ingestion of $\mathrm{TiO}_{2} \mathrm{NPs}$, was reported in studies by Gui et al. [22] and Trouiller et al. [23]. When studying the in vivo toxicity of $\mathrm{TiO}_{2}$ NPs in mice, Chen et al. [24] observed strong symptoms of toxicity, including loss of appetite, tremors, passive behaviour, or lethargy. Furthermore, in a study on rats, Wang et al. [25] observed hepatic oedema, heart damage, and non-allergic activation of mast cells in stomach tissue. Human organism is strongly dependant on its microbiota in terms of, e.g. the ability to digest dietary fibre and other nutrients, modulation of the host immunological response, food transit in the intestines, and defence against pathogens [26].

Interactions between gastrointestinal microbiota and NPs may affect the host's health directly, through NPs-induced modification of the microbiota (increased toxicity), or indirectly, due to dysbiosis of gastrointestinal microorganisms [27]. One should also take into account the fact that various interactions between NPs and gastrointestinal bacteria may be dependent of a wide range of factors, e.g. the surface charge of nanoparticles and bacteria, the surface charge of the digested food, the chemical composition of respective substances and diet components [28], as well as the physicochemical conditions inside the alimentary canal ( $\mathrm{pH}$, enzymes, salts, etc.) [29].

As single-cell organisms, bacteria provide a very good test model for analysing the toxicity of nanoparticles, e.g. to determine their impact on the functional health of a cell organism [30]. Nanoparticles interact with bacteria producing reactive oxygen species (ROS), which in turn can damage DNA, RNA, and proteins [31] (Fig. 1). As follows from research, among the $\mathrm{TiO}_{2} \mathrm{NPs}$, the anatase $\mathrm{TiO}_{2}$ forms are more toxic towards bacteria than rutile NPs as they cause greater

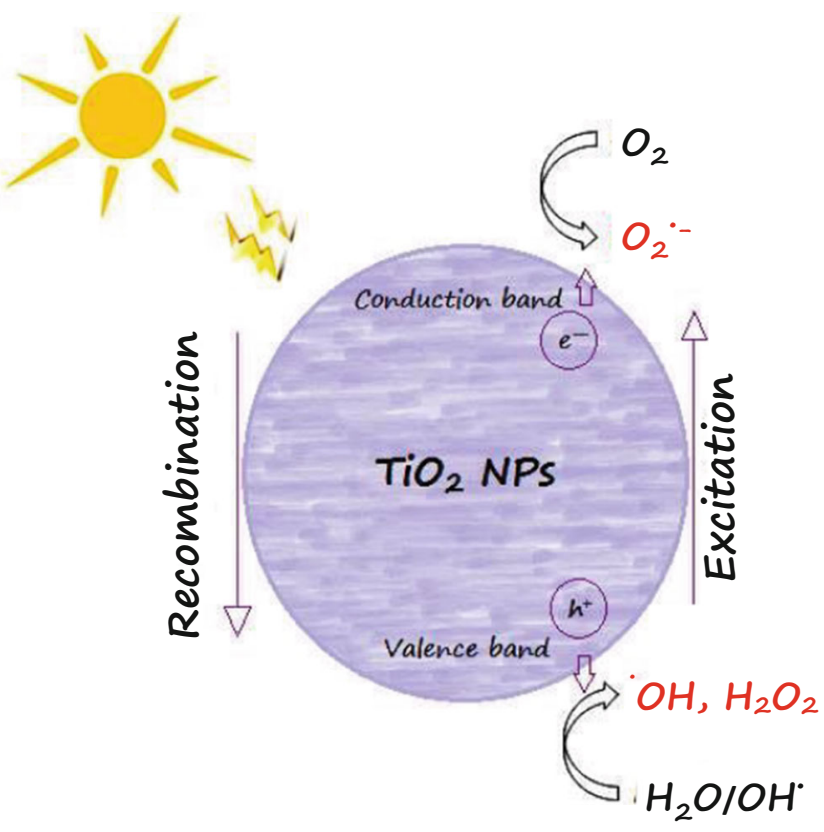

Fig. 1 Mechanism of ROS formation on the surface of titanium oxide nanoparticles

oxidative stress [32, 33]. As reported by Kim et.al [34], mobile (•) $\mathrm{OH}$ is generated in anatase; hence, photocatalytic oxidation therein is easier compared to rutile which can only adsorb a substrate. TiO2 NPs mainly generate electrons and superoxide ions ( $\mathrm{O} 2 \cdot-)$ in the conduction band, as well as positive holes and hydroxyl radicals $(\bullet \mathrm{OH})$ in the valence band. Next, the generated ROS can lead to oxidation of the $\mathrm{TiO} 2 \mathrm{NPs}$ adsorbed on the surfaces of bacteria, leading to their death [35].

Researching the interactions between bacteria and NPs may provide us with a lot of valuable information [30]. There have only been a handful of studies exploring the interactions between NPs and gastrointestinal microbiota, and the resulting impact on the host's health, with most of the same focusing on the direct interactions with the cells of intestinal epithelium [36, 37], as well as photocatalytic applications in UV light (ultraviolet filter) [38].

This review aims to present detailed results of recent studies pertaining to the effects of $\mathrm{TiO} 2 \mathrm{NPs}$ exposure on human intestinal microbiota, as well as factors that may influence the same.

\section{Material and Methods}

A systematic literature survey up to August 2020 was conducted in the following databases: Scopus, PubMed, Web of Science, and Google Scholar (Fig. 2). The following inclusion criteria were employed: studies reporting significant information about the impact of $\mathrm{TiO}_{2}$ nanoparticles on the intestinal 
Fig. 2 Diagram for selection of studies for the systematic review
Articles identified through electronic databased $(n=291)$

Scopus-145 PubMed-25 Web of Science-110 Google scholar-11

Removed Duplicated Articles $(n=87)$

Articles Screened by title and abstract $(n=204)$

Excluded non-relevant articles $(n=140)$

Full text articles assessed for eligibility $(n=64)$

Excluded full texts $(n=2)$

Studies included in review $(n=62)$ microbiota, available in the English language. Articles that did not meet the criteria were excluded. Classical and the newest papers were selected preferentially. The literature search entailed in the separate and joint use of a combination or keywords: "bacteria", microbiota, $\mathrm{TiO}_{2} \mathrm{NPs}$, "impact of $\mathrm{TiO}_{2}$ on bacteria", "impact of $\mathrm{TiO} 2$ on microbiota", "interactions between $\mathrm{TiO}_{2}$ NPs and microbiota". The literature included the following categories of papers: experimental studies and reviews. The obtained literature was manually reviewed, and the cited references were analyzed to identify the relevant studies. The search conducted at the highest sensitivity yielded 291 papers from external databases, which were subsequently collected. Next, after reviewing the titles and synopses, papers not related to the subject matter criteria were excluded, and the remaining texts were analyzed in depth to select the most relevant publications. Eventually, after identifying related papers and studies employing adequate research strategies, a total of 62 articles were analyzed.

\section{Causes and Consequences of Intestinal Microbiota Alterations Due to $\mathrm{TiO}_{2}$ NPs Exposure}

The physiological environment has a considerable significance to the interaction between inorganic nanoparticles and microorganisms [36]. Microorganism colonies can only prosper under specific microenvironmental conditions (e.g. pH, oxygen concentration, symbiotic proximity, nutrient availability) [39]. In the gastrointestinal tract, the environment is shaped by the presence of enzymes, bile, and regions with distinct $\mathrm{pH}$, all of which influence the stability as well as aggregation (and size) of inorganic nanoparticles [29]. The mucous barrier, transit time, and unpredictable peristalsis will condition the transport of food, medicines, as well as the ways in which NPs may potentially interact with our alimentary tract and the microbiota present therein [39] (Fig. 3) [40]. Increased consumption of $\mathrm{TiO}_{2}$ NPs can have a negative impact on the human microbiome in the process of direct food consumption and/or during its passage through the intestine. Commensal bacteria and in-transit bacteria carried with the food can come into contact with $\mathrm{TiO}_{2} \mathrm{NPs}$, which can influence the resident microbiota, and consequently the host's health $[16,41]$. This may lead to inhibition of the growth and activity of gastrointestinal bacteria, in particular of the probiotic type [2]. Microbiota changes can lead to specific health problems including obesity, inflammatory bowel disease, diabetes, and rheumatoid arthritis [36, 42, 43].

Exposure to nanoparticles can take place while consuming food (it is used as pigment, filler, preservative), via the respiratory system or skin $[27,37]$. In the gastrointestinal tract, nanoparticles are first acidized in the stomach, which increases their toxicity due to ion release [37]. In the small intestine, they come in contact with a variety of compounds: proteins and peptides - which can interact with the NPs forming agglomerates as well as changing their charge [44].

There have been reports on the adverse effects of E171 against intestinal epithelial bacteria in vitro [41, 45]. Agans et al. [27] did not exclude potential changes to human intestines following exposure to $\mathrm{TiO}_{2} \mathrm{NPs}$ as the combination of agglomerates in cellular membranes can inhibit cells' ability to divide or disturb the processes of absorbing nutrients. 
Fig. 3 Microbiota population in different organs of the gastrointestinal (GI) tract. Based on Riasat et al. [40]

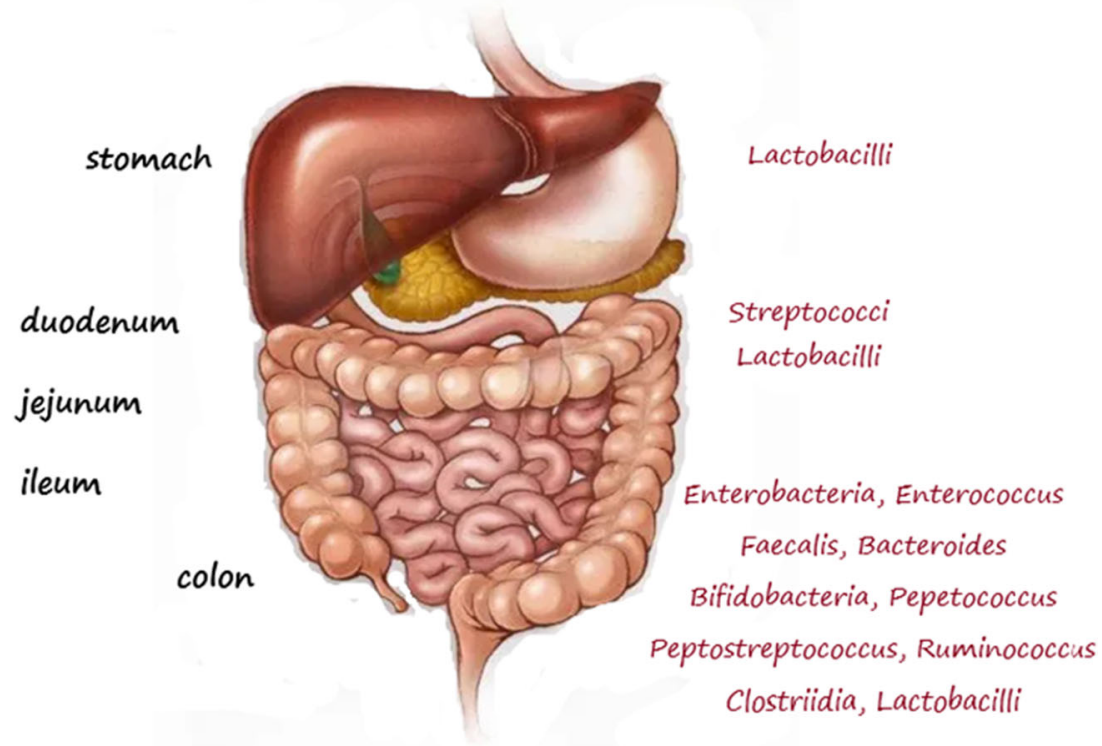

Taylor et al. [46], in a study involving 1-week in vitro exposure to $\mathrm{TiO}_{2}$ NPs (dosed at, respectively, $3 \mu \mathrm{g} / \mathrm{L}, 0.01 \mu \mathrm{g} / \mathrm{L}$, and $0.01 \mathrm{~g} / \mathrm{L}$ ) observed, in the model colon, changes to multiple characteristics of bacteria phenotypes, including the production of short-chain fatty acids. Pignet et al. [47] analyzed the impact of $\mathrm{TiO}_{2} \mathrm{NPs}(2$ and $10 \mathrm{mg} \mathrm{TiO} / 2 / \mathrm{kg}$ bm/day and $50 \mathrm{mg} \mathrm{TiO} / 2 / \mathrm{kg} \mathrm{bm} /$ day) on the large and small intestine in mice. After oral administration of $\mathrm{TiO}_{2} \mathrm{NPs}$, they reported minimum impact of NPs on the composition of gastrointestinal microbiota in mice, but at the same time observed that the same can modify the release of bacterial metabolites in vivo and influence commensal bacteria in vitro by promoting the formation of biofilm. Khan et al. [2] used $\mathrm{TiO}_{2} \mathrm{NPs}$ from purified chocolate and studied its in vitro and in vivo influence on a commercial probiotic preparation typically used in the treatment of diarrhoea in children (it contained Bacillus coagulans, Enterococcus faecalis, and Enterococcus). The researchers demonstrated that $\mathrm{TiO}_{2} \mathrm{NPs}$ obtained from chocolate inhibited the growth and activity of the probiotic preparation within the concentration range of $125-500 \mu \mathrm{g} / \mathrm{mL}$ in vitro. Based on the obtained results, they concluded that $20 \mathrm{~g}$ of the analyzed chocolate contained sufficient amounts of $\mathrm{TiO}_{2}$ NPs to upset the microbiological balance in the intestines of children between 2 and 8 years of age and with a stomach capacity of between 0.5 and $0.9 \mathrm{~L}$; similar effects were observed in an in vivo study on white albino mice dosed at $50-100 \mu \mathrm{g} /$ day/mouse. Pagnout et al. [48] demonstrated that the toxicity of $\mathrm{TiO}_{2} \mathrm{NPs}$ is related to electrostatic interactions between bacteria (Escherichia coli (E. coli)) and nanoparticles, which lead to adsorption of the latter on the cell surface. Planchon et al. [49] corroborated the thesis on the heterogeneity of bacteria populations. In their studies, they demonstrated that after exposure to $\mathrm{TiO}_{2} \mathrm{NPs}$ some bacteria were fully covered with the same, while most of the population remained free from nanoparticles, which resulted in differences in terms of proteome and metabolome. Similarly, Radziwill-Bienkowska et al. [50] observed that a part of the bacterial population remained free form $\mathrm{TiO}_{2} \mathrm{NPs}$, while another part of the same very strongly interacted with the nanoparticles. Furthermore, Waller et al. [28] demonstrated that exposure to $\mathrm{TiO}_{2} \mathrm{NPs}$ caused changes to the composition of microorganisms (i.e. a shift from Proteobacteria to Firmicutes phyla) as well as lowered the colonic $\mathrm{pH}(<5)$ relative to the control $(>5)$.

At the same time, there have been studies that revealed a limited influence of $\mathrm{TiO}_{2}$ NPs on human microbiota. For example, Dudefoi et al. [12] reported that $\mathrm{TiO}_{2} \mathrm{NPs}$ had no significant in vitro impact on gastrointestinal microbiota. Using concentrations that simulated the one observed in an adult intestine after chewing a single piece of chewing gum (100-250 mg/L), they revealed no impact on gas production and only a negligible effect in terms of fatty acid profiles (C16: 00, C18: 00, 15: $1 \mathrm{w} 5 \mathrm{c}, 18: 1 \mathrm{w} 9 \mathrm{c}$ and 18: $1 \mathrm{w} 9 \mathrm{c}$, $p<0.05)$ and phylogenetic composition. Agans et al. [27] demonstrated that $\mathrm{TiO}_{2}$ nanoparticles had limited direct influence on human gastrointestinal microbiota. After adding $\mathrm{TiO}_{2}$ NPs to a microorganic community, some slight reduction was observed but without changes to the overall diversity or balance thereof.

\section{Factors Influencing the Interaction of $\mathrm{TiO}_{2} \mathrm{NPs}$ with the Microbiota, and Their Consequences}

In determining the toxicity of $\mathrm{TiO}_{2} \mathrm{NPs}$, interfacial electrostatic interaction as well as physicochemical parameters of the medium ( $\mathrm{pH}$, ionic strength, electrolyte composition, size, temperature, light exposure) can play a rather significant role $[29,48]$. 


\section{UV}

$\mathrm{TiO}_{2}$ NPs are considered to be chemically inert without photoactivation, but they do show strong photocatalytic and antibacterial properties under UV light as they produce reactive oxygen species (ROS). Anatase is believed to be the most photocatalytically active of all titanium oxides due to its significant mobility of the electron-hole pairs and wider bandwidth range [34].

The mechanism of $\mathrm{TiO}_{2} \mathrm{NPs}$ antibacterial activity under UV light has been fairly thoroughly researched $[35,51]$. Planchon et al. [49] studied the proteome and metabolome of $E$. coli bacteria after exposure to $\mathrm{TiO}_{2} \mathrm{NPs}$ under ultraviolet radiation and in normal light. They observed an ununiform bacterial response to the exposure from $E$. coli cells. A part of the population was able to adapt to the stress and survive for a time; the other part gradually died. The authors believe that some protein and metabolites may be used as biomarker of particle stress, e.g. chaperonin 1 and isocitrate dehydrogenase, as their content was respectively decreased and increased significantly in the presence of $\mathrm{TiO}_{2}$ NPs. Joost et al. [52] demonstrated in their study on living bacteria cells $(E$. coli) that exposure to $\mathrm{TiO}_{2} \mathrm{NPs}$ resulted in enlargement of the cells, deformation of their membranes, and possible cytoplasm leakage after $10 \mathrm{~min}$ of exposure. The complete inactivation of the bacteria in thin $\mathrm{TiO}_{2} \mathrm{NPs}$ layers took place after 20 min UV-A irradiation. The researchers also studied saturated and unsaturated fatty acids present in bacterial plasma membranes, which disintegrated within $10 \mathrm{~min}$ of exposure on photoactivated thin layers of $\mathrm{TiO}_{2} \mathrm{NPs}$. Priyadarshini et al. [53] demonstrated the inhibitive effects of $\mathrm{TiO}_{2}$ NPs in darkness, and enhanced effects under UV light (365 nm), on Gram-positive and Gramnegative bacteria (Staphylococcus aureus (S. aureus), Bacillus subtilis (B. subtilis), and E. coli). The significant bactericidal activity observed already for the minimum $\mathrm{TiO}_{2} \mathrm{NPs}$ concentration (dosed at $0.5 \mathrm{mg} / \mathrm{mL}$ ), and the enhancement thereof after photo-stimulation was explained by the loss of membrane integrity and increased oxidative stress on the surface of bacteria.

Some researchers have reported moderate toxicity of $\mathrm{TiO}_{2}$ NPs towards bacteria, even in the absence of UV radiation [54]. Dark incubation of Gram-negative E. coli and Grampositive $B$. subtilis bacteria with $\mathrm{TiO}_{2}$ nanoparticles reduced the CFU (colony-forming units) index by, respectively, 25\% and $30 \%$ [55]. Also in other studies [56], it was shown that dark incubation of $E$. coli cells with $\mathrm{TiO}_{2} \mathrm{NPs}$ reduced the respective CFU by approximately four orders of magnitude in acidic pH. Zhukova et al. [57] demonstrated that 60-min exposure of $E$. coli to $\mathrm{TiO}_{2} \mathrm{NPs}$ (concentrated at $0.02-0.2 \mathrm{mg}$ / $\mathrm{mL}$ ) resulted in a decrease in cell viability from $10^{8}$ to $10^{4} \mathrm{CFU} / \mathrm{mL}$ (colony-forming unit) in the absence of UV radiation. Qiu et al. [39] demonstrated that $\mathrm{TiO}_{2}$ nanoparticles $(10,50$, and $100 \mathrm{~nm}$ in size $)$ can inhibit the growth of commensal in vitro (Lactobacilli, Enterobacteria and Acetobacter) with no access to light. Radziwill-Bienkowska et al. [50] studied the interactions, under conditions with no UV radiation, between $\mathrm{TiO}_{2}$ NPs (food grade E171 and $\mathrm{TiO}_{2}-\mathrm{P} 25$ ) and gastrointestinal microbiota bacteria (e.g. E. coli) as well as those swallowed with food (e.g. Lactococcus lactis (L. lactis)). They demonstrated that bacterial growth was inhibited by $\mathrm{TiO}_{2} \mathrm{NPs}$ in all the tested bacterial strains (E. coli, L. lactis, Lactobacillus rhamnosus, Lactobacillus sakei, and Streptococcus thermophilus), particularly by the food grade $\mathrm{TiO}_{2} \mathrm{NPs}$. They further observed that E171 may be retained in the intestine by commensal as well as in-transit bacteria carried in food. As a result, physiological changes may occur in more susceptible species.

\section{pH}

Changes in pH significantly impact the surface charge, size, and aggregation speed of NP. Studies indicate that aggregation and stability of food grade and industrial grade $\mathrm{TiO}_{2} \mathrm{NPs}$ is susceptible to solution $\mathrm{pH}$ in terms of particle IEP (isoelectric points) $[58,59]$, where industrial grade particles show IEP at approximately $\mathrm{pH} 6.8$, while food grade particles at approximately pH 3.5 [59]. Lin et al. [60] demonstrated in their study that the toxicity of $\mathrm{TiO}_{2} \mathrm{NPs}$ tends to decrease with growing pH. The antibacterial activity of $\mathrm{TiO}_{2} \mathrm{NPs}(25 \mathrm{~nm}, \mathrm{P} 25)$ against $E$. coli was stronger at $\mathrm{pH} 5.5$ than at 7.0 or 9.5 . Pagnout et al. [48] observed that the viability of E. coli cells was significantly lowered at $\mathrm{pH} 5.5$ compared to $\mathrm{pH} 7.0$ or $\mathrm{pH}$ 9.5. Waller et al. [28] studied, during a 5-day experiment, the impact of exposure to $\mathrm{TiO}_{2} \mathrm{NPs}$ (food and industrial grade) on various bacteria groups from Proteobacteria to Firmicutes phyla. They demonstrated that $\mathrm{TiO}_{2} \mathrm{NPs}$ had only a slight impact on microbiological stability. They also observed that in both cases, exposure to $\mathrm{TiO}_{2} \mathrm{NPs}$ resulted in decreased values of $\mathrm{pH}$ in the colon $(<5)$ compared to the control ( $>5$ ), with the exposure to food grade $\mathrm{TiO}_{2}$ nanoparticles inducing the highest reduction $(\sim \mathrm{pH} 4)$ [28].

\section{Size}

It is suspected that the size of the nano-fraction also influences disorders of gastrointestinal homeostasis as well as the development of intestinal microbiota dysbiosis [59]. Lin et al. [60] studied the toxicity of five types of $\mathrm{TiO}_{2}$ nanoparticles of different sizes (anatase $\mathrm{TiO}_{2}$ NPs with particles sizes of 10 , 25, and $50 \mathrm{~nm}$; rutile $\mathrm{TiO}_{2} \mathrm{NPs}-50 \mathrm{~nm}$; and mixed anatase and rutile $\mathrm{TiO}_{2} \mathrm{NPs}-25 \mathrm{~nm}$ in length). The concentration of anatase $\mathrm{TiO}_{2}$ NPs was observed to increase, particularly for smaller particles, on the surface of Escherichia coli cells. It was also reported that compared to rutile NPs, anatase $\mathrm{TiO}_{2}$ NPs forms were more likely to bind with cell surfaces. Xiong et al. [61] demonstrated that smaller $\mathrm{TiO}_{2}$ NPs after UV-Vis 
activation of a larger surface area had a tendency to produce higher cytotoxicity. The same could be caused by generation of ROS and adsorption of bioparticles, as observed by the authors in whose study, both under biotic and abiotic conditions; ROS production was observed to increase in smaller particles. Ederm et al. [62] demonstrated higher microbiological toxicity for particles under $40 \mathrm{~nm}$. In their study, the highest toxicity was reported for $\mathrm{TiO}_{2} \mathrm{NPs}$ of $16.2 \mathrm{~nm}$ and $21.4 \mathrm{~nm}$ in size, which caused growth inhibition by $80 \%$ (E. coli) and $65 \%$ (B. subtilis) in the absence of light. Under light exposure, $\mathrm{TiO}_{2}$ nanoparticles of the same two sizes also proved to have the highest antibacterial potential.

\section{Conclusion}

The use of titanium dioxide nanoparticles continues to give rise to controversy around the world and is subject to extensive study regarding their impact on the alimentary tract and its functioning. Currently available reports provide contradictory evidence in terms of the impact of inorganic nanoparticles on our microbiota due to the application of varying experimental models and frameworks. Advanced in vivo models need to be developed in experimental conditions to allow a more systematic study necessary for a better understanding of the variations in toxicity observed between NPs and the human microbiota.

\section{Future Perspective}

The review discusses the impact of $\mathrm{TiO}_{2}$ nanoparticles on only a small group of selected bacterial strains. This was a deliberate decision that allowed me to focus on the strains directly related to my currently ongoing studies (research project MINIATURE 3 grant (2019/03/X/NZ9/01032), "Influence of $\mathrm{TiO}_{2}$ nanoparticles on selected lactic and pathogenic bacterial strains, living in the human large intestine"). I aim to study the impact of $\mathrm{TiO}_{2}$ nanoparticles on a dozen or so selected lactic and pathogenic bacterial strains living in the human large intestine. In the study, I also employ an in vitro model of the alimentary tract to determine how the presence of $\mathrm{TIO}_{2} \mathrm{NPs}$ influences the growth of the respective bacteria. This is to allow me to determine the risks related to the presence of those nanoparticles in food. The results detailing the impact of $\mathrm{TiO}_{2} \mathrm{NPs}$ on the respective strains will be presented in the subsequent papers scheduled for publication next year. In the future, I intend to extend the scope of the in vitro studies using bacterial strains obtained from the intestine (Caco-2/ HT29-MTX). It is my considered belief that this line of research may contribute to the minimization or even elimination of the side effects related to the use of $\mathrm{TIO}_{2}$ nanoparticles.
Funding This study was supported by National Science Centre (Poland) in the frame of MINIATURE 3 grant (2019/03/X/NZ9/01032), "Influence of $\mathrm{TiO} 2$ nanoparticles on selected bacterial strains lactic and pathogenic, living in the human large intestine".

\section{Compliance with Ethical Standards}

Conflict of Interest The author declares that he/she has no conflict of interest.

Open Access This article is licensed under a Creative Commons Attribution 4.0 International License, which permits use, sharing, adaptation, distribution and reproduction in any medium or format, as long as you give appropriate credit to the original author(s) and the source, provide a link to the Creative Commons licence, and indicate if changes were made. The images or other third party material in this article are included in the article's Creative Commons licence, unless indicated otherwise in a credit line to the material. If material is not included in the article's Creative Commons licence and your intended use is not permitted by statutory regulation or exceeds the permitted use, you will need to obtain permission directly from the copyright holder. To view a copy of this licence, visit http://creativecommons.org/licenses/by/4.0/.

\section{References}

1. Kumar A, Pandey AK, Singh SS, Shanker R, Dhawan A (2011) Engineered $\mathrm{ZnO}$ and $\mathrm{TiO} 2$ nanoparticles induce oxidative stress and DNA damage leading to reduced viability of Escherichia coli. Free Radic Biol Med 51:1872-1881

2. Khan ST, Saleem S, Ahamed M, Ahmad J (2019) Survival of probiotic bacteria in the presence of food grade nanoparticles from chocolates: an in vitro and in vivo study. Appl Microbiol Biot 103:6689-6700. https://doi.org/10.1007/s00253-019-09918-5

3. Acar MS, Bulut ZB, Ates A, Nami B, Koçak N, Yildiz B (2015) Titanium dioxide nanoparticles induce cytotoxicity and reduce mitotic index in human amniotic fluid-derived cells. Hum Exp Toxicol 34:174-182

4. Coccini T, Grandi S, Lonati D, Locatelli C, De Simone U (2015) Comparative cellular toxicity of titanium dioxide nanoparticles on human astrocyte and neuronal cells after acute and prolonged exposure. NeuroToxicology 48:77-89

5. Bahadar H, Maqbool F, Niaz K, Abdollahi M (2016) Toxicity of nanoparticles and an overview of current experimental models. Iran Biomed J 20(1):1-11

6. Song B, Zhang Y, Liu J, Feng X, Zhou T, Shao L (2016) Is neurotoxicity of metallic nanoparticles the cascades of oxidative stress? Nanoscale Res Lett 11:291

7. Faddah LM, Abdel Baky NA, Al-Rasheed NM, Al-Rasheed NM (2013) Full length research paper: biochemical responses of nanosize titanium dioxide in the heart of rats following administration of idepenone and quercetin. AJPP 7:2639-2651

8. McClements DJ, DeLoid G, Pyrgiotakis G, Shatkin JA, Xiao H, Demokritou P (2016) The role of the food matrix and gastrointestinal tract in the assessment of biological properties of ingested engineered nanomaterials (iENMs): state of the science and knowledge gaps. NanoImpact 3:47-57

9. Allen R (2016) The cytotoxic and genotoxic potential of titanium dioxide (TiO2) nanoparticles on human SH-SY5Y neuronal cells in vitro. The Plymouth Student Scientist 9:5-28

10. Feng X, Chen A, Zhang Y, Wang J, Shao L, Wei L (2015) Central nervous system toxicity of metallic nanoparticles. Int $\mathrm{J}$ Nanomedicine 10:4321-4340 
11. Baranowska-Wójcik E, Szwajgier D, Oleszczuk P, WiniarskaMieczan A (2020) Effects of titanium dioxide nanoparticles exposure on human health - a review. Biol Trace Elem Res 193:118129

12. Dudefoi W, Moniz K, Allen-Vercoe E, Ropers MH, Walker VK (2017) Impact of food grade and nano-TiO2 particles on a human intestinal community. Food Chem Toxicol 106:242-249

13. Bachler G, von Goetz N, Hungerbuhler K (2015) Using physiologically based pharmacokinetic (PBPK) modeling for dietary risk assessment of titanium dioxide ( $\mathrm{TiO} 2)$ nanoparticles. Nanotoxicology 9:373-380

14. Weir A, Westerhoff P, Fabricius L, Hristovski K, Von Goetz N (2012) Titanium dioxide nanoparticles in food and personal care products. Environ Sci Technol 46:2242-2250

15. Sadeghi R, Rodriquez RJ, Yao Y, Kokini JL (2017) Advances in nanotechnology as they pertain to food and agriculture: benefits and risks. Annu Rev Food Sci Technol 8:467-492

16. Zhang C, Derrien M, Levenez F, Brazeilles R, Ballal SA, Kim J, Degivry MC, Quéré G, Garault P, van Hylckama Vlieg JET, Garrett WS, Doré J, Veiga P (2016) Ecological robustness of the gut microbiota in response to ingestion of transient food-borne microbes. Isme J 10:2235-2245

17. Venkatasubbu GD, Baskar R, Anusuya T, Seshan CA, Chelliah R (2016) Toxicity mechanism of titanium dioxide and zinc oxide nanoparticles against food pathogens. Colloid Surface B 148:600606

18. Rhim JW, Park HM, Ha CS (2013) Bio-nanocomposites for food packaging applications. Prog Polym Sci 38:1629-1652

19. EFSA ANS Panel (2016) EFSA panel on food additives and nutrient sources added to food. Scientific opinion on the re-evaluation of titanium dioxide (E171) as a food additive. EFSA J 14:4545

20. Chen Z, Han S, Zhou S, Feng H, Liu Y, Jia G (2020) Review of health safety aspects of titanium dioxide nanoparticles in food application. NanoImpact. 18:100224

21. Brand W, Peters RJB, Braakhuis HM, Maślankiewicz L, Oomen AG (2020) Possible effects of titanium dioxide particles on human liver, intestinal tissue, spleen and kidney after oral exposure. Nanotoxicology:1-23

22. Gui S, Zhang Z, Zheng L, Cui Y, Liu X, Li N, Sang X, Sun Q, Gao G, Cheng Z, Cheng J, Wang L, Tang M, Hong F (2011) Molecular mechanism of kidney injury of mice caused by exposure to titanium dioxide nanoparticles. J Hazard Mater 195:365-370

23. Trouiller B, Reliene R, Westbrook A, Solaimani P, Schiestl RH (2009) Titanium dioxide nanoparticles induce DNA damage and genetic instability in vivo in mice. Cancer Res 69:8784-878969

24. Chen J, Dong X, Zhao J, Tang G (2009) In vivo acute toxicity of titanium dioxide nanoparticles to mice after intraperitioneal injection. J Appl Toxicol 29:330-337

25. Wang Y, Chen Z, Ba T, Pu J, Chen T, Song Y, Gu Y, Qian Q, Xu Y, Xiang K, Wang H, Jia G (2013) Susceptibility of young and adult rats to the oral toxicity of titanium dioxide nanoparticles. Small 9:1742-1752

26. Sekirov I, Russell SL, Antunes LC, Finlay BB (2010) Gut microbiota in health and disease. Physiol Rev 90:859-904

27. Agans RT, Gordon A, Hussain S, Paliy O (2019) Titanium dioxide nanoparticles elicit lower direct inhibitory effect on human gut microbiota than silver nanoparticles. Toxicol Sci 172:411-416. https://doi.org/10.1093/toxsci/kfz183

28. Waller T, Chen C, Walker SL (2017) Food and industrial grade titanium dioxide impacts gut microbiota. Environ Eng Sci 34: $537-550$

29. Jones K, Morton J, Smith I, Jurkschat K, Harding AH, Evans G (2015) Human in vivo and in vitro studies on gastrointestinal absorption of titanium dioxide nanoparticles. Toxicol Lett 1233:95101
30. Jiang W, Mashayekhi H, Xing B (2009) Bacterial toxicity comparison between nano- and micro-scaled oxide particles. Environ Pollut 157:1619-1625

31. Cabiscol E, Tamarit J, Ros J (2000) Oxidative stress in bacteria and protein damage by reactive oxygen species. Int Microbiol 3:3-8

32. Planchon M, Ferrari R, Guyot F, Gélabert A, Menguy N, Chanéac C, Thill A, Benedetti MF, Spalla O (2013) Interaction between Escherichia coli and $\mathrm{TiO} 2$ nanoparticles in natural and artificial waters. Colloid Surface B 102:158-164

33. Jin C, Tang Y, Yang FG, Li XL, Xu S, Fan XF et al (2011) Toxicity of TiO2 nanoparticles in anatase and rutile crystal phase. Biol Trace Elem Res 141:3-15

34. Kim W, Tachikawa T, Moon G, Majima T, Choi W (2014) Molecular-level understanding of the photocatalytic activity difference between anatase and rutile nanoparticles. Angew Chem Int Ed Engl 15:14036-14041

35. Sohm B, Immel F, Bauda P, Pagnout C (2014) Insight into the primary mode of action of $\mathrm{TiO} 2$ nanoparticles on Escherichia coli in the dark. Proteomics 15:98-113

36. Pietroiusti A, Magrini A, Campagnolo L (2016) New frontiers in nanotoxicology: gut microbiota/microbiome-mediated effects of engineered nanomaterials. Toxicol Appl Pharmacol 299:90-95

37. Pietroiusti A, Bergamaschi E, Campagna M, Campagnolo L, De Palma G, Iavicoli S et al (2017) The unrecognized occupational relevance of the interaction between engineered nanomaterials and the gastro-intestinal tract: a consensus paper from a multidisciplinary working group. Part Fibre Toxicol 14:47

38. Pigeot-Rémy S, Simonet F, Errazuriz-Cerda E, Lazzaroni JC, Atlan D, Guillard C (2011) Photocatalysis and disinfection of water: identification of potential bacterial targets. Appl Catal B Environ 104: 390-398

39. Qiu K, Durham PG, Anselmo AC (2018) Inorganic nanoparticles and the microbiome. Nano Res 11:4936-4954. https://doi.org/10. 1007/s12274-018-2137-2

40. Riasat R, Guangjun N, Riasat Z, Aslam I, Sakeena M (2016) Effects of nanoparticles on gastrointestinal disorders and therapy. J Clin Toxicol 6

41. Derrien M, van Hylckama Vlieg JET (2015) Fate, activity, and impact of ingested bacteria within the human gut microbiota. Trends Microbiol 23:354-366

42. Marchesi JR, Adams DH, Fava F, Hermes GD, Hirschfield GM, Hold G et al (2016) The gut microbiota and host health: a new clinical frontier. Gut 65:330-339

43. Liu LY, Sun L, Zhong ZT, Zhu J, Song HY (2016) Effects of titanium dioxide nanoparticles on intestinal commensal bacteria. Nucl Sci Tech 27:1-5

44. Gunawan C, Lim M, Marquis CP, Amal R (2014) Nanoparticleprotein corona complexes govern the biological fates and functions of nanoparticles. J Mater Chem B 2:2060-2083

45. Proquin H, Rodríguez-Ibarra C, Moonen CG, Urrutia Ortega IM, Briedé JJ, de Kok TM et al (2017) Titanium dioxide food additive (E171) induces ROS formation and genotoxicity: contribution of micro and nano-sized fractions. Mutagenesis 32:139-149

46. Taylor AA, Marcus IM, Guysi RL, Walker SL (2015) Metal oxide nanoparticles induce minimal phenotypic changes in a model colon gut microbiota. En Eng Sci 32:602-612

47. Pinget GV, Tan JK, Janac B, Kaakoush NO, Angelatos A, O'sullivan J et al (2019) Impact of the food additive titanium dioxide (E171) on gut microbiota-host interaction. Front Nutr 6:57

48. Pagnout C, Jomini S, Dadhwal M, Caillet C, Thomas F, Bauda P (2012) Role of electrostatic interactions in the toxicity of titanium dioxide nanoparticles toward Escherichia coli. Colloid Surface B 92:315-321

49. Planchon M, LeÂger T, Spalla O, Huber G, Ferrari R (2017) Metabolomic and proteomic investigations of impacts of titanium dioxide nanoparticles on Escherichia coli. PLoS One 12:e0178437 
50. Radziwill-Bienkowska JM, Talbot $\mathrm{P}$, Kamphuis JBJ, Véronique R, Cartier C, Fourquaux I et al (2018) Toxicity of food-grade TiO2 to commensal intestinal and transient food-borne bacteria: new insights using nano-SIMS and synchrotron UV fluorescence imaging. Front Microbiol 9

51. Khan ST, Musarrat J, Al-Khedhairy AA (2016) Countering drug resistance, infectious diseases, and sepsis using metal and metal oxides nanoparticles: current status. Colloid Surface B 146:70-83

52. Joost U, Juganson K, Visnapuu M, Mortimer M Kahru A Nõmmiste E, et al. (2015) Photocatalytic antibacterial activity of nano-TiO2 (anatase)-based thin films: effects on Escherichia coli cells and fatty acids. J Photoch Photobi B 142:178-185

53. Priyadarshini S, Mainal A, Sonsudin F, Yahya R, Alyousef AA, Mohammed A (2019) Biosynthesis of TiO2 nanoparticles and their superior antibacterial effect against human nosocomial bacterial pathogens. Res Chem Intermediat 46:1077-1089. https://doi.org/ 10.1007/s11164-019-03857-6

54. Mallevre F, Fernandes TF, Aspray TJ (2014) Silver, zinc oxide and titanium dioxide nanoparticle ecotoxicity to bioluminescent Pseudomonas putida in laboratory medium and artificial wastewater. Environ Pollut 195:218-225

55. Adams LK, Lyon DY, Alvarez PJJ (2006) Comparative ecotoxicity of nanoscale $\mathrm{TiO} 2, \mathrm{SiO} 2$, and $\mathrm{ZnO}$ water suspensions. Water Res 40:3527-3532

56. Zhukova LV, Kiwi J, Nikandrov VV (2010) Nanoparticles of TiO2 cause aggregation of Escherichia coli cells and suppress their division at $\mathrm{pH} 4.0-4.5$ in the absence of UV irradiation. Dokl Chem 435:279-282

57. Zhukova LV, Kiwi J, Nikandrov V (2012) TiO2 nanoparticles suppress Escherichia coli cell division in the absence of UV irradiation in acidic conditions. Colloid Surface B 97:240-247

58. Chowdhury I, Hong Y, Honda RJ, Walker SL (2011) Mechanisms of $\mathrm{TiO} 2$ nanoparticle transport in porous media: role of solution chemistry, nanoparticle concentration, and flowrate. J Colloid Interface Sci 360:548-555

59. Yang Y, Doudrick K, Bi X, Hristovski K, Herckes P, Westerhoff P, Kaegi R (2014) Characterization of food-grade titanium dioxide: the presence of nanosized particles. Environ Sci Technol 48: 6391-6400

60. Lin X, Li J, Ma S, Liu G, Yang K, Tong M, Lin D (2014) Toxicity of $\mathrm{TiO} 2$ nanoparticles to Escherichia coli: effects of particle size, crystal phase and water chemistry. PLoS One 9:e110247

61. Xiong S, George S, Ji Z, Lin S, Yu H, Damoiseaux R et al (2012) Size of $\mathrm{TiO} 2$ nanoparticles influences their phototoxicity: an in vitro investigation. Arch Toxicol 87:99-109

62. Erdem A, Metzler D, Cha DK, Huang CP (2015) The short-term toxic effects of $\mathrm{TiO} 2$ nanoparticles toward bacteria through viability, cellular respiration, and lipid peroxidation. Environ Sci Pollut R 22:17917-17924

Publisher's Note Springer Nature remains neutral with regard to jurisdictional claims in published maps and institutional affiliations. 